\title{
PERENCANAAN APARTEMEN 10 LANTAI DENGAN SISTEM GANDA SRPMK DAN SHEARWALL UNTUK KOTA CIANJUR
}

\author{
${ }^{1}$ Tanjung Rahayu, ${ }^{2}$ Zulkifli \\ Program Studi Teknik Sipil Fakultas Teknik Universitas Suryakancana \\ tanjungrahayu@yahoo.com, zulforbusiness@gmail.com
}

\begin{abstract}
Abstrak
Apartemen pada perencanaan kali ini terletak dikota Cianjur dengan luas bangunan $824 m^{2}$ yang memiliki jumlah lantai 10 lantai yang memiliki tinggi total bangunan 40,5m diasumsikan bahwa apartemen ini dibangun diatas tanah keras (kelas situs SC), bangunan ini menggunakan metode sistem ganda gabungan antara sistem rangka pemikul momen khusus dan dinding geser yang mengacu pada SNI-1726-2012 tata cara perencanaan ketahanan gempa untuk struktur bangunan gedung dan nongedung, pembebanan nongempa mengacu pada SNI-1727-2013 beban minimum untuk perencanaan bangunan gedung dan struktur lain. Struktur sekunder berupa tangga dan struktur primer berupa kolom, balok, pelat, dinding geser. Keseluruhan struktur adalah beton dengan mengacu pada SNI-2847-2013 tata cara perhitungan struktur beton untuk bangunan gedung, setelah dianalisis menggunakan gempa dinamik respon spectrum dan dicek terhadap jumlah ragam, simpangan antar lantai, $p$-delta, redundansi, ketidakberaturan horisontal dan vertikal didapat ukuran kolom 55x55, 45x90 cm, ukuran dinding geser $35 \mathrm{~cm}$, ukuran balok 30x70, $30 \times 50,25 \times 35 \mathrm{~cm}$, dan ukuran pelat $14,15 \mathrm{~cm}$
\end{abstract}

Kata Kunci : Perencanaan, struktur beton bertulang, sistem ganda, SRPMK dan dinding geser

\section{PENDAHULUAN}

Kota Cianjur terletak di daerah rawan gempa, untuk mengurangi resiko akibat bencana gempa tersebut perlu direncanakan struktur bangunan tahan gempa. Jika bangunan tahan gempa tidak direncanakan dengan baik dapat mengakibatkan kerugian baik itu secara material maupun moril serta banyak menimbulkan korban jiwa. Berdasarkan SNI-17262012 yaitu Cara Perencanaan Ketahanan Gempa Untuk Struktur Bangunan Gedung dan Non Gedung, untuk merencanakan bangunan tahan gempa, struktur bangunan gedung harus memiliki sistem penahan gaya lateral dan vertikal yang lengkap, yang mampu memberikan kekuatan, kekakuan yang cukup untuk menahan gerak tanah desain dalam batasan-batasan kebutuhan deformasi dan kekuatan yang disyaratkan.

Perencanaan bangunan apartemen ini direncanakan dengan menggunakan material beton bertulang sesuai dengan SNI-2847-2013 yaitu Persyaratan Beton Struktural Untuk Bangunan Gedung, dan sistem struktur yang akan direncanakan adalah sistem struktur ganda yaitu kombinasi antara Sistem Rangka Pemikul Momen Khusus (SRPMK) dengan Sistem Dinding Shearwall (SDS).

\section{A. Rumusan Masalah}

1. Bagaimana proses perencanaan bangunan tahan gempa yang menggunakan sistem ganda untuk memikul beban lateral?

2. Bagaimana perhitungan penulangan kolom, balok, plat, dan shearwall, untuk beton bertulang?

\section{B. Tujuan Penelitian}

1. Untuk mengetahui bagaimana proses perencanaan bangunan tahan gempa yang menggunakan sistem ganda (SRPMK dan shearwall).

2. Untuk mengetahui bagaimana perhitungan penulangan kolom, balok, plat, dan shearwall.

\section{Batasan Masalah}

Agar pembahasan ini dapat terarah pada tujuan utama, maka perlu dibuat suatu batasan-batasan masalah. Adapun batasan-batasan masalah sebagai berikut :

1. Membahas perhitungan penulangan hanya untuk struktur atas seperti (kolom, balok, plat, shearwall) tidak termasuk dengan struktur bawah bangunan (pondasi).

2. Pembahasan sistem ganda hanya berkombinasi antara Sistem Rangka Pemikul Moment Khusus (SRPMK) dengan dinding geser (shearwall). 


\section{TINJAUAN PUSTAKA}

A. Peraturan Perhitungan Konstruksi

Dalam perencanaan, peraturan yang digunakan antara lain:

1. SNI-1727-2013 Beban minimum untuk perancangan bangunan gedung dan struktur lain.

2. Persyaratn beton struktur untuk bangunan gedung SNI-2847-2013.

3. Tata cara perencanaan ketahanan gempa untuk struktur bangunan gedung dan non gedung SNI1726-2012.

B. Lokasi

Lokasi perencanaan berada pada Cianjur, Muka, Kec. Cianjur, Kabupaten Cianjur, Jawa Barat 43215 $($ Lintang $=-6.811953980417172$, bujur $=$ 107.14518916554563)

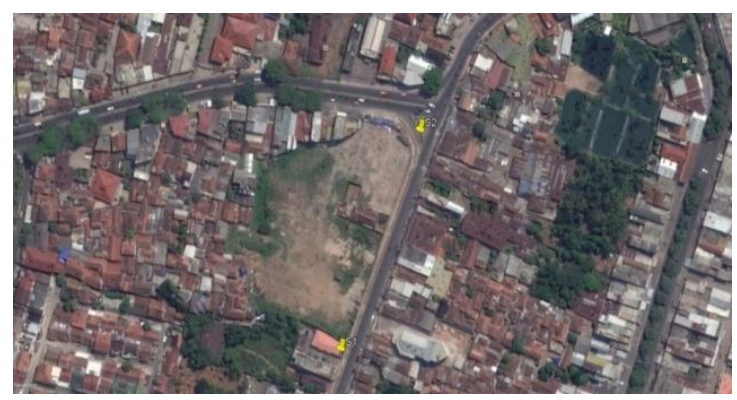

Gambar 1. Lokasi perencanaan

\section{METODOLOGI}

\section{A. Flow chart}

Garis besar langkah-langkah perencanaan struktur gedung disajikan dalam bentuk flowchart seperti pada Gambar 2.

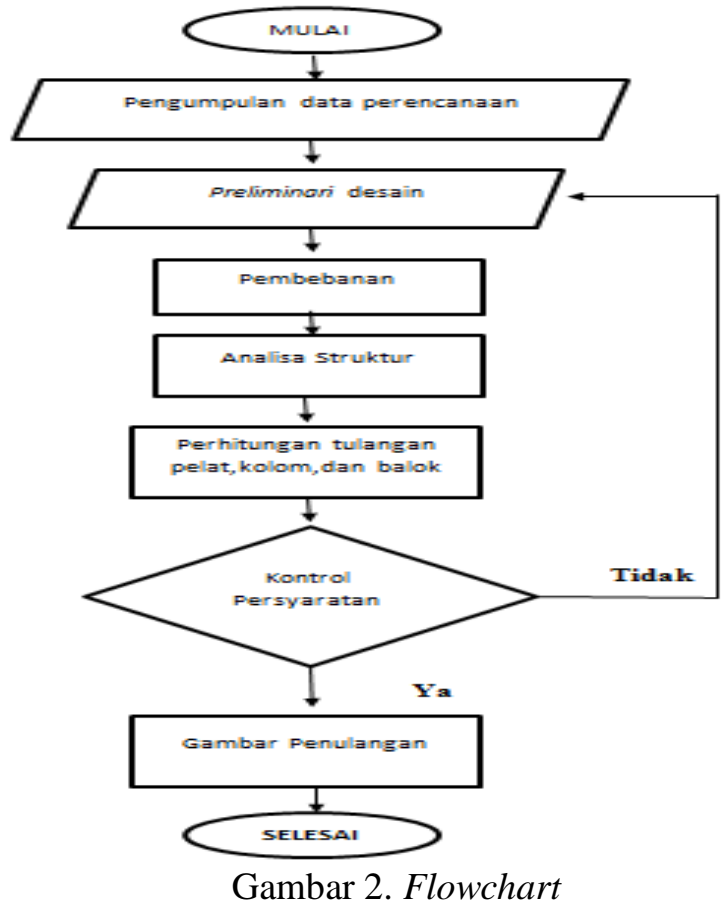

\section{PEMBAHASAN}

\section{A. Permodelan Struktur Secara 3D}

Perencanaan struktur gedung menggunakan beton bertulang dengan mutu beton $\mathrm{fc}=35 \mathrm{MPa}$ untuk kolom dan shearwall $\mathrm{fc}=30 \mathrm{Mpa}$ untuk balok dan pelat, dan mutu baja fy $=390 \mathrm{Mpa}$ untuk tulangan ulir dan fy $=240 \mathrm{Mpa}$ untuk tulangan polos. Permodelan gedung apartemen 10 lantai secara 3D seperti pada Gambar 3.

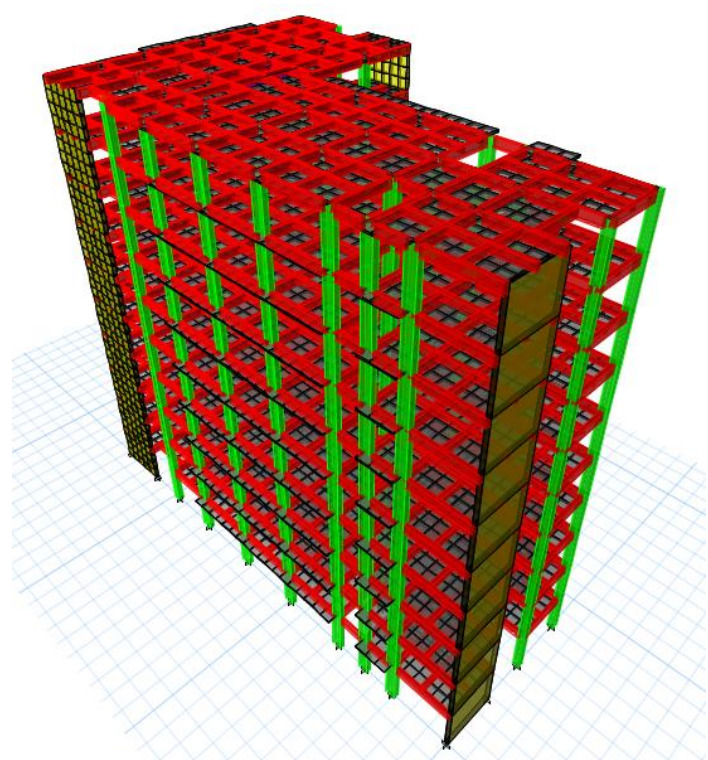

Gambar 3. Permodelan struktur 3D

\section{B. Kombinasi Pembebanan}

Beban yang diperhitungkan dalam perencanaan gedung apartemen ini adalah sebagai berikut.

- Beban mati (D)

- Beban hidup (L)

- Beban gempa (E)

\section{Kombinasi pembebanan yang} digunakan adalah sebagai berikut:

- $\quad 1,4 \mathrm{D}$

- $\quad 1,2 \mathrm{D}+1,6 \mathrm{~L}$

- $\quad(1,2+1,2 \mathrm{Sds}) \mathrm{D} \pm \rho \mathrm{E}_{\mathrm{x}} \pm(0,3 \rho) \mathrm{E}_{\mathrm{y}}+\mathrm{L}$

- $\quad(1,2+1,2 \mathrm{Sds}) \mathrm{D} \pm \rho \mathrm{E}_{\mathrm{y}} \pm(0,3 \rho) \mathrm{E}_{\mathrm{x}}+\mathrm{L}$

- $\quad(0,9-0,2 S d s) \mathrm{D} \pm \rho \mathrm{E}_{\mathrm{x}} \pm(0,3 \rho) \mathrm{E}_{\mathrm{y}}$

- $\quad(0,9-0,2 \mathrm{Sds}) \mathrm{D} \pm \rho \mathrm{E}_{\mathrm{y}} \pm(0,3 \rho) \mathrm{E}_{\mathrm{x}}$

\section{Analisis Struktur Terhadap Beban Gempa}

Analisis struktur gedung tahan gempa ditentukan berdasarkan konfigurasi struktur, fungsi struktur, dan peta zonasi gempa sesuai dengan SNI-17262012, digunakan data-data seperti berikut:

- $\quad$ Lokasi bangunan = Cianjur

- Faktor keutamaan (Ie) $\quad=1$

- $\quad$ Kategori risiko = IV 
- Koefisien modifikasi respons $(\mathrm{R})=7$ (Sistem Ganda SRPMK dan Dinding Geser)

- $\quad$ Faktor kuat lebih sistem $(\Omega)=2,5$

- $\quad$ Faktor pembesaran defleksi $(C d)=5,5$

Dengan memasukkan data lokasi perencanaan pada halaman yang dibuat oleh PU http://puskim.pu.go.id/Aplikasi/desain_spektra_in donesia_2011/, seperti pada Gambar 4 berikut:

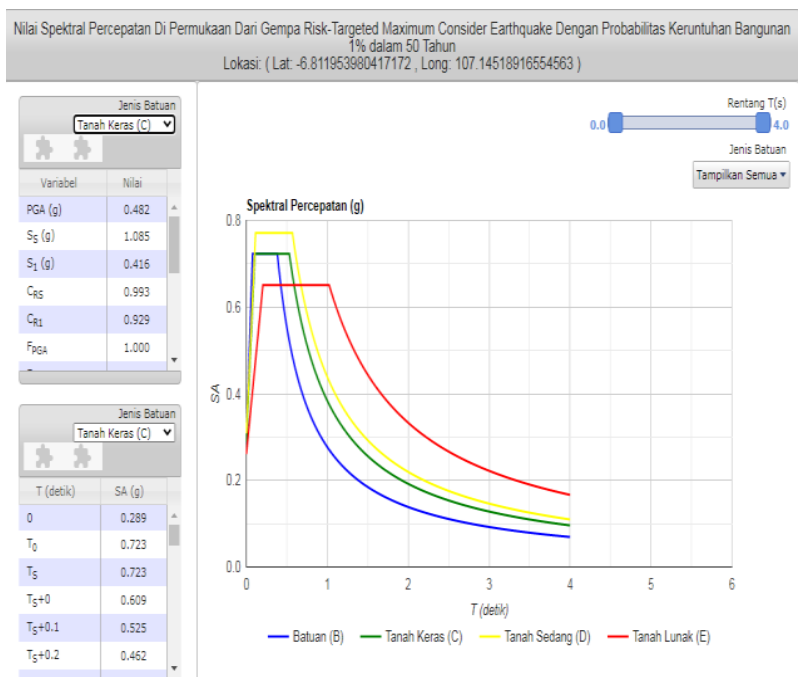

Gambar 4. Nilai Sds, Sd1, Ss, S1

Didapatkan nilai-nilai seperti berikut:

- Percepatan respons spektral desain pada perioda pendek $(\mathrm{Sds})=0,723$

- Percepatan respons spektral pada perioda 1 $\operatorname{detik}(\mathrm{Sd} 1)=0,384$

- Percepatan respons spektral MCE dari peta gempa pada perioda pendek $(\mathrm{Ss})=1,085$

- Percepatan respons spektral MCE dari peta gempa pada perioda 1 detik $(\mathrm{S} 1)=0,416$

Permodelan respons spectrum dibantu software Etabs dengan memasukkan nilai SS,dan S1 dan didapatkan grafik seperti pada gambar 5 berikut:

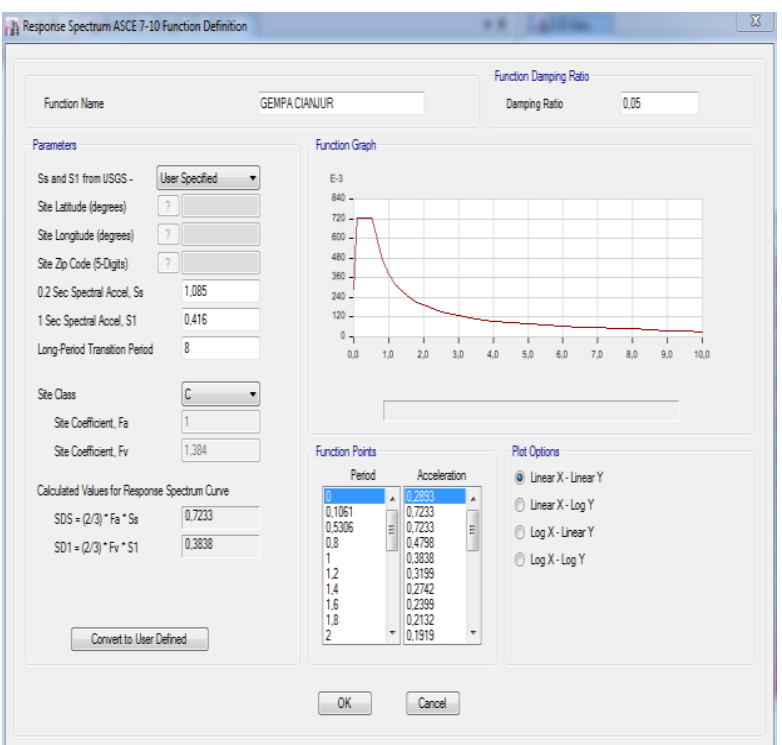

Gambar 5. Respons spectrum

\section{E. Partisipasi Massa}

Partisipasi massa ragam (sum ux/uy) minimal sebesar 90 persen pada masing-masing arah horisontal ortogonal (ux dan uy), jika tidak maka harus ada perubahan bentuk struktur atau memperbesar dimensi strukturnya, niali partisipasi massa dapat dilihat pada tabel 1 berikut:

Tabel 1. Partisipasi mass

\begin{tabular}{cccc}
\hline Mode & Period & $\begin{array}{c}\text { Jumlah Ux } \\
\text { (Sum Ux) }\end{array}$ & $\begin{array}{c}\text { Jumlah Uy } \\
\text { (Sum Uy) }\end{array}$ \\
\hline 1 & 2,084 & 0,6214 & 0,0187 \\
\hline 2 & 1,922 & 0,7433 & 0,4207 \\
\hline 3 & 1,791 & 0,7788 & 0,7854 \\
\hline 4 & 0,619 & 0,8917 & 0,7858 \\
\hline 5 & 0,581 & 0,8933 & 0,873 \\
\hline 6 & 0,543 & 0,8944 & 0,8989 \\
\hline 7 & 0,32 & 0,9408 & 0,899 \\
\hline 8 & 0,302 & 0,941 & 0,9425 \\
\hline 9 & 0,275 & 0,9416 & 0,9437 \\
\hline 10 & 0,202 & 0,9656 & 0,9438 \\
\hline 11 & 0,191 & 0,9657 & 0,9678 \\
\hline 12 & 0,167 & 0,9667 & 0,9679 \\
\hline
\end{tabular}

\section{F. Gaya Geser Dasar}

Berdasarkan SNI-1726-2012 nilai gaya geser dinamik tidak boleh kurang dari 85 persen gaya geser statik, nilai-nilai tersebut dapat dilihat pada tabel 2 berikut: 
Tabel 2. Perbandingan gaya geser statik dan dinamik

\begin{tabular}{ccc}
\hline Gaya & $\begin{array}{c}85 \text { persen statik } \\
(\mathrm{kN})\end{array}$ & $\begin{array}{c}\text { Dinamik } \\
(\mathrm{kN})\end{array}$ \\
\hline $\mathrm{Vx}$ & 4471,424 & 4471,45 \\
\hline $\mathrm{Vy}$ & 4471,424 & 4471,45 \\
\hline
\end{tabular}

\section{G. Simpangan Antar Lantai}

Untuk sistem struktur SRPMK simpangan ijin ditentukan dengan persamaan:

$0,020 . \mathrm{h}$

Dimana:

$\mathrm{h} \quad=$ tinggi setiap tingkatnya

Hasil perhitungan simpangan antar lantai dapat dilihat pada tabel 3 dan 4 berikut:

Tabel 3. Simpangan antar lantai arah $\mathrm{x}$

\begin{tabular}{cccc}
\hline $\begin{array}{c}\mathrm{h} \\
(\mathrm{mm})\end{array}$ & $\begin{array}{c}\delta \mathrm{xe} \\
(\mathrm{mm})\end{array}$ & $\delta \mathrm{x}(\mathrm{mm})$ & $\begin{array}{c}\text { Simpangan } \\
\text { ijin }(\mathrm{mm})\end{array}$ \\
\hline 4000 & 4,883 & 26,8565 & 80 \\
\hline 4000 & 6,274 & 34,507 & 80 \\
\hline 4000 & 7,535 & 41,4425 & 80 \\
\hline 4000 & 8,677 & 47,6685 & 80 \\
\hline 4000 & 9,688 & 53,284 & 80 \\
\hline 4000 & 10,421 & 57,3155 & 80 \\
\hline 4000 & 10,702 & 58,861 & 80 \\
\hline 4000 & 10,31 & 56,705 & 80 \\
\hline 4000 & 8,858 & 48,719 & 80 \\
\hline 4500 & 5,466 & 30,063 & 90 \\
\hline
\end{tabular}

Tabel 4. Simpangan antar lantai arah y

\begin{tabular}{cccc}
\hline $\begin{array}{c}\mathrm{h} \\
(\mathrm{mm})\end{array}$ & $\begin{array}{c}\delta \mathrm{xe} \\
(\mathrm{mm})\end{array}$ & $\delta \mathrm{x}(\mathrm{mm})$ & $\begin{array}{c}\text { Simpangan ijin } \\
(\mathrm{mm})\end{array}$ \\
\hline 4000 & 3,953 & 21,7415 & 80 \\
\hline 4000 & 5,005 & 27,5275 & 80 \\
\hline 4000 & 6,111 & 33,6105 & 80 \\
\hline 4000 & 7,108 & 39,094 & 80 \\
\hline 4000 & 7,996 & 43,978 & 80 \\
\hline 4000 & 8,651 & 47,5805 & 80 \\
\hline 4000 & 8,953 & 49,2415 & 80 \\
\hline 4000 & 8,727 & 47,9985 & 80 \\
\hline 4000 & 7,624 & 41,932 & 80 \\
\hline 4500 & 4,844 & 26,642 & 90 \\
\hline
\end{tabular}

\section{H. Pengaruh P-delta}

Struktur tahan gempa harus memperhitungkan pengaruh p-delta, Koefisien stabilitas $(\Theta)$ tidak boleh melebihi (Өmax) yang ditentukan perumusan berikut:

Өmax $=0,5 / \beta . C_{d}<0,25$
Dimana:

$$
\begin{aligned}
\Theta \max = & \text { koefisien stabilitas (Teta max) } \\
\beta= & \text { rasio kebutuhan geser terhadap } \\
& \text { kapasitas geser untuk antar tingkat, } \\
& \text { rasio ini diijinkan secara } \\
& \text { konservatif diambil sebesar 1 } \\
\mathrm{Cd}= & \text { faktor pembesaran defleksi }
\end{aligned}
$$

Hasil perhitungan pengaruh p-delta dapat dilihat pada tabel 5 dan 6 berikut:

Tabel 5. P-delta arah x

\begin{tabular}{ccc}
\hline $\mathrm{h}(\mathrm{mm})$ & Teta $(\Theta)$ & Teta $\max (\Theta \max )$ \\
\hline 4000 & 0,0107 & 0,09091 \\
\hline 4000 & 0,0170 & 0,09091 \\
\hline 4000 & 0,0254 & 0,09091 \\
\hline 4000 & 0,0342 & 0,09091 \\
\hline 4000 & 0,0412 & 0,09091 \\
\hline 4000 & 0,0480 & 0,09091 \\
\hline 4000 & 0,0536 & 0,09091 \\
\hline 4000 & 0,0564 & 0,09091 \\
\hline 4000 & 0,0531 & 0,09091 \\
\hline 4500 & 0,0321 & 0,09091 \\
\hline
\end{tabular}

Tabel 6. P-delta arah y

\begin{tabular}{ccc}
\hline $\mathrm{h}(\mathrm{mm})$ & Teta $(\Theta)$ & Teta $\max (\Theta \max )$ \\
\hline 4000 & 0,0092 & 0,09091 \\
\hline 4000 & 0,0141 & 0,09091 \\
\hline 4000 & 0,0210 & 0,09091 \\
\hline 4000 & 0,0281 & 0,09091 \\
\hline 4000 & 0,0340 & 0,09091 \\
\hline 4000 & 0,0398 & 0,09091 \\
\hline 4000 & 0,0448 & 0,09091 \\
\hline 4000 & 0,0477 & 0,09091 \\
\hline 4000 & 0,0457 & 0,09091 \\
\hline 4500 & 0,0285 & 0,09091
\end{tabular}

\section{Sistem Ganda}

Struktur untuk perencanaan kali ini menggunakan sistem ganda, maka sistem rangka pemikul moment harus mampu menahan paling sedikit 25 persen gaya gempa desain. Gaya geser yang ditinjau terletak pada perletakan-perletakan atau joint shearwall pada lantai dasar, untuk nilai-nilainya terdapat pada tabel 7 berikut: 
Tabel 7. P-delta arah y

\begin{tabular}{|l|c|c|c|c|c|}
\hline Gaya & $\begin{array}{c}\text { Gaya geser } \\
\text { shearwall } \\
\text { arah } \mathrm{x}(\mathrm{kN})\end{array}$ & $\begin{array}{c}\text { Gaya geser } \\
\text { shearwall } \\
\text { arah } \mathrm{y}(\mathrm{kN})\end{array}$ & $\begin{array}{c}\text { Gaya geser } \\
\operatorname{arah} \mathrm{x}(\mathrm{kN})\end{array}$ & $\begin{array}{c}\text { Gaya geser } \\
\text { arah } \mathrm{y}(\mathrm{kN})\end{array}$ & $\begin{array}{c}\text { Persentase } \\
\text { gaya pada } \\
\text { shearwall }\end{array}$ \\
\hline Gempa X & 1130,79 & & 4471,4249 & & 25,289 \\
\hline Gempa $\mathrm{Y}$ & & 696,96 & & 4471,4249 & 15,587 \\
\hline
\end{tabular}

\section{J. Ketidakberaturan Horisontal}

struktur ini memiliki 2 ketidakberaturan horisontal yaitu:

- $\quad$ ketidak beraturan torsi

- ketidakberaturan sudut dalam

struktur ini harus memenuhi persyaratan dalam pasal-pasal yang dapat dilihat pada (SNI-17262012 Tabel 10), pasal yang harus dipenuhi seperti berikut:

- Pasal 7.3.3.4 (peningkatan gaya akibat ketidakberaturan untuk kategori desain seismik D hingga F)

- Pasal 7.7.3 (permodelan struktur)

- Pasal 7.8.4.3 (pembesaran momen torsi takterduga)

- Pasal 7.12.1 (batasan simpangan antar lantai tingkat)

\section{K. Ketidakberaturan Vertikal}

struktur ini tidak mengalami ketidakberaturan vertikal

\section{Perhitungan Struktur}

a. Perhitungan Pelat

- mutu beton $(\mathrm{Fc})(\mathrm{Mpa})=30$

- $\quad$ tegangan leleh baja U39 $(\mathrm{Fy})(\mathrm{Mpa})=390$

- tebal plat $(\mathrm{h})(\mathrm{mm})=140$

- tebal selimut beton (ts) (mm) $=20$

- Rasio tulangan pada kondisi balance, $\rho_{\mathrm{b}}=$ $\beta_{1} \cdot 0,85 . f_{c} / f_{y} \cdot 600 /\left(600+f_{y}\right)=0,0331$

- Rasio tulangan maksimum $=\rho_{\max }=((0,003$ + fy / Es ) / 0,008) $. \rho_{b}=0,0205$

- Faktor tahanan momen maksimum, $R_{\max }=0,9 \cdot \rho_{\max } \cdot f_{y} \cdot\left[1-\rho_{\max } \cdot f_{y} /(1,7\right.$. $\left.\left.\mathrm{f}_{\mathrm{c}}{ }^{\prime}\right)\right]=6,0628$

- Momen numinal rencana $(\mathrm{Mn})(\mathrm{kNm})=$ $\mathrm{Mu} / \mathrm{\Theta}=28,684$

- Faktor tahanan momen $(\mathrm{Rn})=\mathrm{Mn} \cdot 10^{-6} /\left(\mathrm{b} \cdot \mathrm{d}^{2}\right)=2,2266$

- Rasio tulangan digunakan $(\rho)=0,006$

- Luas tulangan yang diperlukan (As) $\left(\mathrm{mm}^{2}\right)$ $=\rho \cdot b \cdot d=679$

- Jarak tulangan yang diperlukan $(\mathrm{s})(\mathrm{mm})=$ $\pi / 4 . D^{2} . b / A s=195$

- Digunakan tulangan arah X D13 - 150

- Digunakan tulangan arah Y D13 - 150
Tabel 8. Kebutuhna tulangan pelat

\begin{tabular}{cccc}
\hline Pelat & $\begin{array}{c}\text { Tebal } \\
(\mathrm{mm})\end{array}$ & $\begin{array}{c}\text { Tulangan } \\
\text { arah X }\end{array}$ & $\begin{array}{c}\text { Tulangan } \\
\text { arah Y }\end{array}$ \\
\hline P1 & 140 & D13-150 & D13-150 \\
\hline P2 & 140 & D13-150 & D13-150 \\
\hline P3 & 150 & D13-150 & D13-150 \\
\hline
\end{tabular}

\section{b. Perhitungan Balok}

- Syarat balok SRPMK

Gaya aksial tekan terfaktor pada komponen struktur lentur dibatasi maksimum 0,1 . Ag . Fc: $\mathrm{Ag}=\mathrm{b} . \mathrm{h}=2100000,1 . \mathrm{Ag} \cdot \mathrm{Fc}=630 \mathrm{kN}$ Gaya aksial tekan akibat beban kombinasi gaya gempa dan gravitasi $\mathrm{Ev}=0,2 . \mathrm{Sds} . \mathrm{D} \mathrm{Qu} . \mathrm{Ln}$ $+0,2$. Sds . D = $48 \mathrm{kN} 630>48$ aman

- Bentang bersih komponen struktur tidak boleh kurang dari 4 kali tinggi efektif (d') Ln / d = $8,63>4$ aman

- Perbandingan lebar balok terhadap tinggi balok tidak boleh kurang dari $0,3 \mathrm{~B} / \mathrm{h}=0,43>0,3$ aman

- Lebar balok tidak boleh: Kurang dari $250 \mathrm{~mm}=$ $300>250$ aman Melebihi 0,75 lebar kolom = $(0,75$. 450) $=337,5=300<337,5$ aman

- Pengecekan nilai $\mathrm{Vc}$

$\mathrm{Vpr}=(\mathrm{Mpr} b 1+\mathrm{Mpr} \mathrm{b} 2) / \mathrm{Ln}=201,077 \mathrm{Kn}$

$\mathrm{Vg}=1,2 \mathrm{D}+1 \mathrm{~L}=84,6592 \mathrm{kN}$

$\mathrm{Ve}=\mathrm{Vpr}+\mathrm{Vg}=285,736$

- Nilai tahanan geser beton $(\mathrm{Vc})$ harus bernilai 0 jika $\mathrm{Vpr}>1 / 2 \mathrm{Ve}$, dan $\mathrm{Pu}<\mathrm{Ag}$. Fc / 20. Vpr $(201,077)>1 / 2 \mathrm{Ve}(142,868) \mathrm{Pu}(48)<\mathrm{Ag}$. Fc / 20 (1260) Maka nilai Vc harus bernilai 0

Dikarenakan Ve $(285,736)<\mathrm{Vu}(345,135)$ maka gaya geser pada tumpuan digunakan nilai $\mathrm{Vu}=345,135$

Jarak sengkang maksimum $($ SNI-2847-2013) $=\mathrm{d} / 4=156,25$

Jarak sengkang maksimum $($ SNI-2847-2013) $=6 . \mathrm{D}=132$

Jarak sengkang maksimum

$($ SNI-2847-2013 $)=150=150$

Tabel 9. Kebutuhna tulangan balok

\begin{tabular}{|l|l|l|l|l|l|}
\hline Tipe balok & \multirow{2}{*}{$\begin{array}{l}\text { Ukuran balok } \\
(\mathrm{mm})\end{array}$} & \multicolumn{2}{|l|}{ Tumpuan } & \multicolumn{2}{l|}{ Lapangan } \\
\cline { 3 - 6 } & & Atas & Bawah & Atas & Bawah \\
\hline $\mathrm{B} 1$ & $300 \times 700$ & 7D22 & 4D22 & 3D22 & 5D22 \\
\hline $\mathrm{B} 2$ & $300 \mathrm{X} 500$ & 6D22 & 3D22 & 2D22 & 4D22 \\
\hline $\mathrm{B}$ a & 250X350 & 3D16 & 2D16 & 2D16 & 2D16 \\
\hline
\end{tabular}




\section{c. Perhitungan Kolom}

- Syarat kolom SRPMK Perbandingan lebar dengan tinggi tidak kurang dari 0,4 dan $300 \mathrm{~mm}$ $\mathrm{b} / \mathrm{h}=450 / 900=0,5>0,4$, aman $\mathrm{b}=450>$ $300 \mathrm{~mm}$, aman

- Luas tulangan longitudinal tidak boleh kurang dari $0,01 \mathrm{Ag}$ (luas penampang) dan tidak boleh lebih dari 0,06Ag Ag = b . $\mathrm{h}=405000 \mathrm{~mm}^{2}$

- Luas tulangan . jumlah tulangan $=\left(1 / 4 . \pi .22^{2}\right)$ $.24=9118,56 \mathrm{~mm}^{2}$

- Luas tulangan longitudinal $=9118,56 / 405000$ $=0,0225$, aman

- Kolom kuat balok lemah $(\mathrm{Mn} \mathrm{c1}+\mathrm{Mn}$ c2 $)>1,2$ (Mn b1 + Mn b2) 3936,55 > 839,8 aman

- Tulangan transversal

0,3 . $(\mathrm{Ag} \cdot$ Ach -1$) /(\mathrm{Fc} / \mathrm{Fy})=0,00901$ $0,09 .(\mathrm{Fc} / \mathrm{Fy})=0,00807$

Syarat jarak tulangan transversal (s) seperti berikut: $1 / 4 . b=112,5 \mathrm{~mm}$

6 kali diameter tulangan longitudinal $=132 \mathrm{~mm}$ So $=100+((350-\mathrm{xi}) / 3)=159,67$

So tidak perlu melebihi $=150 \mathrm{~mm}$

So tidak perlu kurang dari $=100 \mathrm{~mm}$

So pakai $=100 \mathrm{~mm}$

- Lokasi daerah sendi plastis kolom(Lo)

Tinggi penampang komponen struktur $=\mathrm{h}=$ $900 \mathrm{~mm}, 1 / 6$ bentang komponen struktur $=1 / 6$. $\mathrm{L}=666,667 \mathrm{~mm}$

Tidak boleh kurang dari $=450 \mathrm{~mm}$

Lo pakai $=1000 \mathrm{~mm}$

Tabel 10. Kebutuhna tulangan kolom

\begin{tabular}{ccc}
\hline $\begin{array}{c}\text { Tipe } \\
\text { kolom }\end{array}$ & $\begin{array}{c}\text { Ukuran } \\
\text { kolom }(\mathrm{mm})\end{array}$ & Tulangan \\
\hline $\mathrm{K} 1$ & 450X900 & 24D22 \\
\hline $\mathrm{K} 2$ & $550 \mathrm{X} 550$ & 16D22 \\
\hline
\end{tabular}

\section{d. Perhitungan Shearwall}

nilai gaya geser $(\mathrm{V})>0,083$. Acv $\cdot \lambda$. $\sqrt{ } \mathrm{Fc}$ maka menggunakan tulangan minimum 0,0025 Dipasang tulangan 2D13-200 $=265,33 \mathrm{~mm}^{2}$

Vs $=(($ Avt. fy.$d) / s)=2483489 N$

$\rho=($ Avt $/(\mathrm{Tw} . \mathrm{s}))=0,00379$

$\rho=0,00379>\rho \min =0,0025$

$\mathrm{Hw} / \mathrm{lw}=0,75<1,5$ maka $\alpha \mathrm{c}=0,25$

Acv $=2100000 \mathrm{~mm}^{2}$

$\rho \mathrm{t}=\mathrm{As} / \mathrm{Tw} \cdot \mathrm{s}=0,00379$

$\mathrm{Vn}=\mathrm{Acv} \cdot(\alpha \mathrm{c} \cdot \lambda \cdot \sqrt{\mathrm{Fc}}+\mathrm{pt} \cdot \mathrm{Fy})=6210303 \mathrm{~N}$

$\Theta=0,6$

$\Theta . \mathrm{Vn}=3726,18 \mathrm{kN}$

$\Theta \operatorname{Vn}(3726,18)>\mathrm{V}(1480,8)$, aman
Tabel 11. Kebutuhna tulangan shearwall

\begin{tabular}{cccc}
\hline $\begin{array}{c}\text { Tipe } \\
\text { shearwall }\end{array}$ & $\begin{array}{c}\text { Tebal } \\
(\mathrm{mm})\end{array}$ & $\begin{array}{c}\text { Bentang } \\
(\mathrm{m})\end{array}$ & Tulangan \\
\hline Sw1 & 350 & 6 & $\mathrm{D} 13-200$ \\
\hline Sw2 & 350 & 5 & $\mathrm{D} 16-200$ \\
\hline
\end{tabular}

\section{e. Perhitungan Hubungan Balok Kolom}

$\operatorname{Ve}(\mathrm{kN})=(\mathrm{Mpr} b 1 . \mathrm{Df}+\mathrm{Mpr} \mathrm{b} 2 . \mathrm{Df}) / \mathrm{L}=$ 142,87

Jumlah tulangan momen negatif area tumpuan balok $=7 \mathrm{D} 22$

Luas tulangan 7 D $22\left(\right.$ As) $\left(\mathrm{mm}^{2}\right)=2659,5$

$\mathrm{T} 1(\mathrm{kN})=1,25$. As .fy $=1296,5$

$\mathrm{C} 1(\mathrm{kN})=\mathrm{T} 1=1296,5$

Jumlah tulangan momen positif area tumpuan balok $=4 \mathrm{D} 22$

Luas tulangan 4 D $22($ As $)\left(\mathrm{mm}^{2}\right)=1519,7$

$\mathrm{T} 2(\mathrm{kN})=1,25$. As $. \mathrm{fy}=740,88$

$\mathrm{C} 2(\mathrm{kN})=\mathrm{T} 2=740,88$

Gaya geser pada HBK

$(\mathrm{Vj})(\mathrm{kN})=(\mathrm{C} 1+\mathrm{C} 2-\mathrm{Ve})=1894,5$

Tahanan geser HBK

$(\mathrm{Vn})(\mathrm{kN})=1,7 \cdot V_{\mathrm{fc}} \cdot \mathrm{Aj}=3771,1$

Faktor reduksi $(\Theta)=0,75$

$\Theta V n(2828,3)>\operatorname{Vj}(1894,55)$ aman

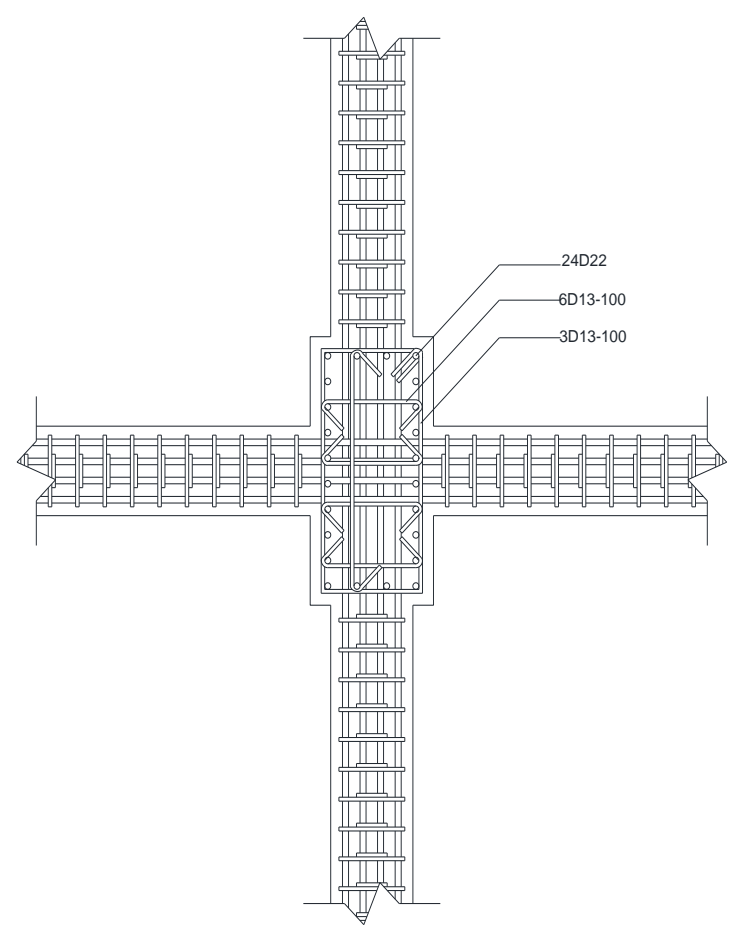

Gambar 6. Detail penulangan HBK tengah 


\section{KESIMPULAN DAN SARAN}

\section{A. Kesimpulan}

Berdasarkan keseluruhan hasil analisis yang telah dilakukan dapat ditarik kesimpulan sebagai berikut:

1. Perencanaan struktur gedung apartemen didaerah Cianjur berkategori desain seismik (KDS) D dan kategori risiko II direncanakan dengan metode ganda yaitu Sistem Rangka Pemikul Momen Khusus (SRPMK) dan dinding geser, dan direncanakan dengan perhitungan gempa dinamik.

2. Struktur telah lolos pengecekan: jumlah ragam, simpangan antar lantai, p-delta, sistem ganda, ketidakberaturan horisontal, ketidakberaturan vertikal, redudansi.

3. Hasil analisis struktur seperti berikut:

a. Kolom

\begin{tabular}{|c|c|c|c|c|c|}
\hline \multirow{2}{*}{$\begin{array}{c}\text { Tipe } \\
\text { kolom }\end{array}$} & \multirow{2}{*}{$\begin{array}{c}\text { Dimensi } \\
(\mathrm{mm})\end{array}$} & \multirow{2}{*}{$\begin{array}{c}\text { Tulangan } \\
\text { utama }\end{array}$} & \multicolumn{3}{|c|}{ Tulangan geser } \\
\cline { 4 - 5 } & & & $\begin{array}{c}\text { tumpuan } \\
\text { lapangan lebar } \\
(\mathrm{b})\end{array}$ & $\begin{array}{c}\text { Arah } \\
\text { panjang (h) }\end{array}$ & \\
\hline $\mathrm{K} 1$ & 450x900 & 24D22 & 3D13-100 & 6D13-100 & 2D13-100 \\
\hline $\mathrm{K} 2$ & $550 \times 550$ & 16D22 & 4D13-100 & 4D13-100 & 2D13-100 \\
\hline
\end{tabular}

b. Shearwall

\begin{tabular}{|c|c|c|c|c|}
\hline Bentang $(\mathrm{m})$ & Tebal $(\mathrm{mm})$ & $\begin{array}{c}\text { Jumlah } \\
\text { tulangan }\end{array}$ & $\begin{array}{c}\text { Tulangan } \\
\text { vertikal }\end{array}$ & $\begin{array}{c}\text { Tulangan } \\
\text { horisontal }\end{array}$ \\
\hline 6 & 350 & $62 \mathrm{D} 13$ & $2 \mathrm{D} 13-200$ & $2 \mathrm{D} 13-200$ \\
\hline 5 & 350 & $52 \mathrm{D} 16$ & $2 \mathrm{D} 16-200$ & $2 \mathrm{D} 16-200$ \\
\hline
\end{tabular}

c. Balok

\begin{tabular}{|c|c|c|c|c|c|c|c|}
\hline \multirow{3}{*}{ tipe } & \multirow{3}{*}{$\begin{array}{l}\text { Dimensi } \\
\text { (mm) }\end{array}$} & \multicolumn{4}{|c|}{ Tulangan lentur } & \multirow{2}{*}{\multicolumn{2}{|c|}{ Tulangan geser }} \\
\hline & & \multicolumn{2}{|c|}{ Tumpuan } & \multicolumn{2}{|c|}{ lapangan } & & \\
\hline & & $\begin{array}{c}\text { Tul } \\
\text { atas }\end{array}$ & $\begin{array}{c}\text { Tul } \\
\text { bawah }\end{array}$ & $\begin{array}{l}\text { Tul } \\
\text { atas }\end{array}$ & $\begin{array}{c}\text { Tul } \\
\text { bawah }\end{array}$ & Tumpuan & lapangan \\
\hline $\begin{array}{c}\text { Balok } \\
\text { induk } 1\end{array}$ & $300 \times 700$ & 7D22 & $4 \mathrm{D} 22$ & $3 \mathrm{D} 22$ & $5 \mathrm{D} 22$ & $\begin{array}{c}\text { 4D13- } \\
100\end{array}$ & $\begin{array}{c}\text { 2D13- } \\
200\end{array}$ \\
\hline $\begin{array}{c}\text { Balok } \\
\text { induk } 2\end{array}$ & $300 \times 500$ & $6 \mathrm{D} 22$ & 3D22 & $4 \mathrm{D} 22$ & $2 \mathrm{D} 22$ & $\begin{array}{c}\text { 3D13- } \\
100\end{array}$ & $\begin{array}{c}\text { 2D13- } \\
200\end{array}$ \\
\hline $\begin{array}{c}\text { Balok } \\
\text { anak }\end{array}$ & $250 \times 350$ & $3 \mathrm{D} 16$ & $2 \mathrm{D} 16$ & 2D16 & $2 \mathrm{D} 16$ & $\begin{array}{c}2 \varnothing 12- \\
200\end{array}$ & $\begin{array}{c}2 \varnothing 12- \\
200\end{array}$ \\
\hline $\begin{array}{c}\text { Balok } \\
\text { tangga }\end{array}$ & $150 \times 300$ & $2 \varnothing 12$ & $2 \varnothing 12$ & $2 \varnothing 12$ & $2 \varnothing 12$ & $\begin{array}{c}2 \emptyset 10- \\
200\end{array}$ & $\begin{array}{c}2 \varnothing 10- \\
200\end{array}$ \\
\hline
\end{tabular}

d. Pelat

\begin{tabular}{|c|c|c|c|}
\hline Tipe & Tebal $(\mathrm{mm})$ & Tul arah $\mathrm{x}$ & Tul arah $\mathrm{x}$ \\
\hline Pelat lantai & 140 & D13-150 & D13-150 \\
\hline Pelat lift & 150 & D13-150 & D13-150 \\
\hline Pelat tangga & 140 & D13-200 & D13-200 \\
\hline
\end{tabular}

e. Hubungan balok kolom (HBK)

\begin{tabular}{|l|l|l|l|l|l|l|l|}
\hline Tipe & Sengkang & $\mathrm{Tl}(\mathrm{kN})$ & $\mathrm{Cl}(\mathrm{kN})$ & $\mathrm{Vu}(\mathrm{kN})$ & $\mathrm{Vn}(\mathrm{kN})$ & $0,75 \mathrm{Vn}$ & $\mathrm{Cek}$ \\
\hline $\mathrm{K} 1$ & $6 \mathrm{D} 13-100$ & 1296,5 & 1296,5 & 1894,5 & 3771,1 & 2828,3 & $0 \mathrm{k}$ \\
\hline $\mathrm{K} 2$ & $4 \mathrm{D} 13-100$ & 1296,5 & 1296,5 & 1106,1 & 1988,2 & 1491,1 & $0 \mathrm{k}$ \\
\hline
\end{tabular}

\section{B. Saran}

Dalam perencanaan suatu struktur harus dilakukan studi yang lebih mendalam dengan mempertimbangkan aspek teknis, ekonomi dan estetika, sehingga diharapkan perencanaan dapat dilaksanakan mendekati sesungguhnya.

\section{DAFTAR PUSTAKA}

Agus Setiawan, 2016, Perancangan Struktur Beton Bertulang Berdasarkan SNI 2847-2013, Yogyajarta : Erlangga.

Asroni, A, 2010. Balok dan Pelat Beton Bertulang, Yogyakarta : Graha Ilmu

Kementerian Pekerjaan Umum, 2012, SNI-28472002 Tata Cara Perhitungan Struktur Beton Untuk Bangunan Gedung. Bandung.

Kementerian Pekerjaan Umum, 2012, SNI-17262012 Tata Cara Perencanaan Ketahanan Gempa Untuk Struktur Bangunan Gedung Dan Non Gedung. Bandung.

Kementerian Pekerjaan Umum, 2012, SNI-17272013 Beban Minimum Untuk Perancangan Bangunan Gedung Dan Struktur Lain. Bandung.

Kementerian Pekerjaan Umum, 2012, SNI-28472013 Persyaratan Beton Struktural Untuk Bangunan Gedung.Bandung.

Merriam-Webster.com. 15 Maret, 2021. Steel. 2021, dari https://www.merriamwebster.com/dictionary/steel/. Diakses pada 21 Maret 2021

Pujianto, A. 2011. Struktur Komposit Dengan Metode LRFD: MIT Press. https://ekhalmussaad.files.wordpress.com/2 011/03/7-komposit.doc. Diakses pada 21 Maret 2021

Schodek, Daniel L, 1999. Struktur Edisi kedua, Jakarta : Erlangga.

Sudarmoko 1996, Diagram Perancangan Kolom Beton Betulang, Jurusan Teknik Sipil, Fakultas Teknik, Universitas Gadjah Mada, Yogyakarta. 